\title{
Cloning, expression and antiviral activity of mink alpha-interferons
}

Hai-ling Zhang ${ }^{1}$, Jian-jun Zhao ${ }^{1}$, Xiu-li Chai ${ }^{1}$, Lei Zhang ${ }^{1}$, Xue Bai ${ }^{1}$, Bo Hu${ }^{1}$, Hao Liu' ${ }^{1}$ Dong-liang Zhang ${ }^{2}$, Ming Ye ${ }^{2}$, Wei $\mathrm{Wu}^{2}$ and $\mathrm{Xi-jun} \mathrm{Yan}^{1^{*}}$

\begin{abstract}
Background: As a key link between innate and adaptive immune responses, the interferon (IFN) system is the first line of defense against viral infection. IFN, and in particular, IFN-a, has been used clinically as an effective therapeutic agent for viral infections. However, different subtypes of IFN-a demonstrate distinct antiviral activity. Therefore, it is important to identify IFN-a subtypes with high antiviral activity for the development of genetically engineered antiviral drugs.

Results: In this study, we cloned the genes for 13 IFN-a subtypes from peripheral blood lymphocytes of the mink. The homologies of the 13 mink IFN-a genes were $93.6-99.3 \%$ and $88.8-98.4 \%$ at the nucleotide and amino acid sequence levels, respectively. In contrast to human and canine IFN-a subtypes, most mink IFN-a subtypes contained two N-glycosylation sites. We expressed and purified 13 mink IFN-a subtypes in Escherichia coli. The cytopathic effect inhibition assay showed that all the 13 recombinant mink IFN-a subtypes inhibited the propagation of vesicular stomatitis virus in WISH cells, with IFN-a2 and IFN-a12 demonstrating the highest activities. Furthermore, recombinant mink IFN-a2 and IFN-a12 significantly suppressed the propagation of canine distemper virus in Vero cells, with IFN-a2 demonstrating the highest activity.
\end{abstract}

Conclusions: We identified the mink IFN-a2 subtype as a promising candidate for the development of effective antiviral drugs.

Keywords: Mink, Interferon subtype, Antiviral activity

\section{Background}

Interferon (IFN) was first identified by Isaacs in 1957 [1]. IFN belongs to the cytokine family of proteins and has a wide range of physiological functions, such as inhibiting viral infection, regulating cell proliferation and differentiation, and modulating immune responses [2]. The IFN system is one of the first defensive barriers against viral infection and is an important component of natural antiviral immunity [3,4].

IFNs are key cytokines with antiviral, antitumor, and immunomodulatory activities. Based on gene sequences, chromosome location, and receptor specificity, the members of the IFN family are classified into I, II, and III subtypes. Subtype I includes IFN- $\alpha, \beta, \omega, \varepsilon, \kappa, \delta$ and $\zeta$

\footnotetext{
*Correspondence: yanxijun@163.com

'Division of Infectious Diseases of Special Economic Animal, Institute of Special Animal and Plant Sciences, Chinese Academy of Agricultural Sciences, 4899 Juye Street, Changchun 130112, China

Full list of author information is available at the end of the article
}

[5-8], and type I IFNs have been shown to possess effective antiviral activity. Type II IFN is also known as immune IFN (IFN- $\gamma$ ) [9]. Interferon- $\gamma$, a cytokine produced by $\mathrm{T}$ lymphocytes and natural killer cells, plays a central role in the modulation of the immune response [10]. The type III interferons are also known as the IFN- $\lambda s$ and are more related to type I IFNs based on their amino acid sequence and protein function. However, the more limited tissue expression of IFN- $\lambda$ receptors suggests that type III IFNs do not simply recapitulate the type I IFN antiviral system. They have antiviral effects in the respiratory tract, gastrointestinal tract, skin mucosa, epithelial cells, and some tumor cells. Among the IFN family, IFN- $\alpha$ is one of the major modulators of the defensive system against viral infection in mammals and has been widely used in the clinic as a therapeutic for viral infection [11,12]. All IFNs identified in vertebrates are secreted proteins, with IFN- $\alpha$ being secreted from virus-infected white blood cells. The human IFN family 
consists of 13 subtypes. Despite differences in their amino acid sequences, the subtypes of human IFN- $\alpha$ have similar 3D structures and similar physiological and biochemical characteristics, such as stability and recognition by surface receptors. Human IFN- $\alpha$ is composed of 166-172 amino acids and has no glycosylation sites. The average molecular weight of IFN- $\alpha$ is about $19 \mathrm{kDa}$. The homology of amino acids among IFN- $\alpha$ s from different subtypes ranges from about $75-95 \%$ [13]. The IFN- $\alpha$ s can be further classified into subtypes, which have different biological functions.

IFN is a conserved molecule that has been found in humans, mouse, sheep, rabbits, dogs, weasels and other mammals, as well as in fish, turtles and insects. IFNs have been used in both human and veterinary medicine, not only for the treatment of viral infections but also for cancer. Mink (Neovison vison) is one of the major fur animals and its health problems have become an important issue for the fur industry. Infection by the canine distemper virus, Parvovirus, and Aleutian mink disease virus among minks has caused serious economic losses to the fur animal industry [14]. Therefore, there is an urgent need to develop effective, non-toxic, and environmentally friendly antiviral drugs to control viral infections in mink. In this study, we cloned and expressed the genes for 13 IFN- $\alpha$ subtypes in the mink and characterized their antiviral activity.

\section{Results}

\section{Analysis of mink IFN-a genes}

By reverse transcription polymerase chain reaction (RT-PCR), we successfully amplified the predicted 564 bp mink IFN- $\alpha$ (MiIFN- $\alpha)$ cDNA. Restriction enzyme analysis confirmed that we had correctly subcloned MiIFN- $\alpha$ cDNAs into recombinant plasmids. DNAStar software analysis demonstrated that the cDNAs of 13 subtypes of MiIFN- $\alpha$ were 564 bp long and encoded 187 amino acids. Due to the different amino acids components, there were slight variations in molecular weight among the 13 MiIFN- $\alpha$ subtypes. The GenBank registration number and molecular weight of the cloned 13 MiIFN- $\alpha$ subtypes are listed in Table 1.

SignalP 4.1 server software (http://www.CBS.DTU.DK/ Services/SignalP) analysis predicted that the $\mathrm{N}$ terminal 23 amino acids represented the signal peptide. The homologies of 13 MiIFN- $\alpha$ subtypes were $93.6-99.3 \%$ and $88.8-98.3 \%$ at the nucleotide and amino acid sequence levels, respectively (Table 2 ).

Most secreted proteins in eukaryotes are modified on the amino acid Asn located in the consensus sequence Asn.Xaa.Ser/Thr (NXS/T) by an $\mathrm{N}$-glycan, a process known as N-glycosylation [15]. Analysis using NetNGlyc Server 1.0 (http://www.CBS.DTU.DK/Services/NetNGlyc)
Table 1 The 13 MilfN- $a$ subtypes cloned in this study

\begin{tabular}{lcl}
\hline IFN-a subtype & MW (Da) & Accession number \\
\hline MilFN-a1 & 20956 & EU863613 \\
MilFN-a2 & 20999 & EU863614 \\
MilFN-a3 & 20958 & EU863615 \\
MilFN-a4 & 21031 & EU863616 \\
MilFN-a5 & 21089 & EU863617 \\
MilFN-a6 & 21204 & EU863618 \\
MilFN-a7 & 21002 & EU863619 \\
MilFN-a8 & 21032 & EU863620 \\
MilFN-a9 & 21021 & EU863621 \\
MilFN-a10 & 21146 & EU863622 \\
MilFN-a11 & 21248 & EU863623 \\
MilFN-a12 & 21060 & EU863624 \\
IFN-a13 & 20983 & EU091340 \\
\hline
\end{tabular}

predicted that IFN- $\alpha 1-3$ contained one glycosylation site at ${ }^{54} \mathrm{NYTN}^{57}$, whereas IFN- $\alpha 4-13$ contained two glycosylation sites. In addition to the glycosylation site at ${ }^{54} \mathrm{NYTN}^{57}$, IFN- $\alpha 4-9$ and IFN- $\alpha 13$ contained a glycosylation site at ${ }^{101} \mathrm{NTTL}^{104}$, whereas IFN- $\alpha 10-12$ contained a glycosylation site at ${ }^{101}$ NMTL $^{104}$. Further analysis demonstrated that the number and position of cysteines were not the same among the 13 subtypes. IFN- $\alpha 1-3$, IFN- $\alpha 5$, IFN$\alpha 7$, IFN- $\alpha 10$, IFN- $\alpha 11$ and IFN- $\alpha 13$ contained 8 cysteine residues at the same positions of $5,16,24,52,92,109,122$ and 160 . IFN- $\alpha 4$, IFN- $\alpha 6$, IFN- $\alpha 8$, IFN- $\alpha 9$ and IFN- $\alpha 12$ contained only 7 cysteine residues with a cysteine residue at position 16 replaced by serine (Figure 1). These data demonstrate the existence of a single nucleotide polymorphism (SNP) among MiIFN- $\alpha$ subtypes, in agreement with previous reports on SNPs of IFN- $\alpha$ in other species $[15,16]$.

Both mink and ferret belong to Mustelidae. The homology between IFN- $\alpha 1-13$ and the published sequences for ferret (GenBank registration number: EF368207) were $95.0-97.3 \%$ and $91.5-94.2 \%$ at the nucleotide and amino acid sequence levels, respectively. The amino acid sequence analysis showed that fox (EF990625), raccoon (EF543192), and canine (EF28625) IFN- $\alpha$ each contained only one potential Nglycosylation site at ${ }^{101} \mathrm{NMTL}^{104}$, which is the same site in MiIFN- $\alpha 10-12$. The homologies between mink, fox, raccoon and canine IFN- $\alpha$ were $79.1-80.9 \%$ and $68.8-71.4 \%$ at the nucleotide and amino acid sequence levels, respectively. Nucleotide evolution tree analysis showed significant differences in the nucleotide sequences among the 13 subtypes of MiIFN- $\alpha$ and those of other species of animals and human IFN- $\alpha$ s (Figure 2). 
Table 2 Homology (\%) of amino acids and nucleotides among MilFN-a subtypes

\begin{tabular}{|c|c|c|c|c|c|c|c|c|c|c|c|c|c|}
\hline & IFN- $a 1$ & IFN-a2 & IFN-a3 & IFN-a4 & IFN-a5 & IFN-a6 & IFN- $\alpha 7$ & IFN- $a 8$ & IFN- $a 9$ & IFN-a10 & IFN-a11 & IFN-a12 & IFN-a13 \\
\hline IFN-al & - & 99.3 & 97.0 & 95.0 & 96.3 & 94.5 & 94.7 & 94.7 & 93.8 & 94.7 & 94.3 & 96.1 & 95.4 \\
\hline IFN-a2 & 98.4 & - & 96.6 & 95.7 & 97.0 & 95.2 & 94.7 & 94.9 & 94.0 & 94.3 & 94.0 & 95.7 & 95.0 \\
\hline IFN-a3 & 94.7 & 94.1 & - & 96.3 & 96.8 & 94.7 & 96.3 & 96.6 & 95.7 & 96.3 & 95.2 & 98.0 & 95.6 \\
\hline IFN-a4 & 90.4 & 92.0 & 93.0 & - & 98.8 & 98.4 & 96.5 & 96.3 & 95.4 & 96.6 & 95.0 & 95.7 & 96.1 \\
\hline IFN-a5 & 93.0 & 94.7 & 93.6 & 97.3 & - & 97.2 & 97.0 & 96.1 & 95.2 & 97.0 & 95.6 & 95.6 & 96.1 \\
\hline IFN-a6 & 89.3 & 90.9 & 91.4 & 98.4 & 95.7 & - & 95.2 & 95.0 & 94.3 & 95.0 & 96.3 & 94.7 & 95.6 \\
\hline IFN-a7 & 91.4 & 90.9 & 93.0 & 93.6 & 94.1 & 92.5 & - & 96.8 & 96.3 & 97.9 & 97.2 & 95.2 & 96.3 \\
\hline IFN-a8 & 90.9 & 90.9 & 94.1 & 92.5 & 92.0 & 91.4 & 94.1 & - & 99.1 & 95.9 & 94.3 & 97.3 & 95.6 \\
\hline IFN-a9 & 89.3 & 89.3 & 92.5 & 90.9 & 90.4 & 89.8 & 93.6 & 98.4 & - & 95.0 & 93.6 & 96.5 & 94.7 \\
\hline IFN-a10 & 91.4 & 90.9 & 94.1 & 94.7 & 95.2 & 93.0 & 96.8 & 92.0 & 90.4 & - & 97.2 & 96.3 & 96.3 \\
\hline IFN-a11 & 89.8 & 89.3 & 92.0 & 92.5 & 93.0 & 94.1 & 95.2 & 90.4 & 88.8 & 96.8 & - & 94.9 & 95.7 \\
\hline IFN-a12 & 93.0 & 92.5 & 97.3 & 92.5 & 92.0 & 91.4 & 92.0 & 95.2 & 93.6 & 93.6 & 92.0 & - & 95.6 \\
\hline IFN-a13 & 91.4 & 90.9 & 91.4 & 92.0 & 92.5 & 91.4 & 93.6 & 90.4 & 88.8 & 93.6 & 93.0 & 90.4 & - \\
\hline
\end{tabular}

"-" same sequence. The upper line shows identities at the nucleotide level; The lower line shows identities at the amino acid level. The sequences for alignment were from the following GenBank accession numbers: IFN-a1 (MilFN-a1, EU863613), IFN-a2 (MilFN-a2, EU863614), IFN-a3 (MilFN-a3, EU863615), IFN-a4 (MilFN-a4, EU863616), IFN-a5 (MilFN-a5, EU863617), IFN-a6 (MilFN-a6, EU863618), IFN-a7(MilFN-a7, EU863619), IFN-a8 (MilFN-a8, EU863620), IFN-a9 (MilFN-a9, EU863621), IFN-a10 (MilFN-a10, EU863622), IFN-a11 (MilFN-a11, EU863623), IFN-a12 (MilFN-a12, EU863624), IFN-a13 (MilFN-a13, EU091340).

\section{Expression and purification of MilFN-a in E. coli}

To evaluate the biological activity of MiIFN- $\alpha$, we subcloned 13 MiIFN- $\alpha$ cDNAs into a prokaryotic expression vector pProEX $\mathrm{HTb}$ and induced their expression by isopropyl-beta-D-thiogalactopyranoside (IPTG) in E. coli BL21. Sodium dodecyl sulfate (SDS)-polyacrylamide gel electrophoresis (PAGE) analysis showed the presence of protein bands at $19 \mathrm{kDa}$ (Figure 3A), consistent with the predicted molecular weights of MiIFN- $\alpha$. Protein solubility analysis showed that MiIFN- $\alpha$ recombinant proteins were in the form of inclusion bodies. SDS-PAGE analysis of the isolated inclusion bodies showed that $80 \%$ of recombinant proteins were in inclusion bodies. Western blot analysis of partially purified MiIFN- $\alpha$ with an anti-6xHis antibody showed a specific band of about 19 kDa (Figure 3B).

\section{Antiviral activity of recombinant MilFN-a}

To examine the antiviral activity of recombinant MiIFN- $\alpha \mathrm{s}$, we first used the WISH/ vesicular stomatitis virus (VSV) system. Compared to the cells without virus infection, challenge of WISH cells with 100 TCID $_{50}$ VSV for $24 \mathrm{~h}$ resulted in significant cell lesions. However, pretreatment with 13 subtypes of MiIFN- $\alpha$ attenuated VSVinduced cell lesions, with MiIFN- $\alpha 2$ and MiIFN- $\alpha 12$ demonstrating the strongest effects. Further analysis showed that the effective antiviral concentrations of MiIFN- $\alpha 2$ and MiIFN- $\alpha 12$ in WISH cells were $0.18 \times 10^{4}$ $\mathrm{IU} / \mathrm{mg}$ and $0.3 \times 10^{3} \mathrm{IU} / \mathrm{mg}$, respectively.

To confirm that the antiviral activity of recombinant MiIFN- $\alpha$ is not limited to VSV, we employed the canine distemper virus (CDV)/Vero system. We selected
MiIFN- $\alpha 2$ and MiIFN- $\alpha 12$, because these two subtypes exhibited the strongest antiviral activity against VSV. The results showed that recombinant MiIFN- $\alpha 2$ and MiIFN- $\alpha 12$ significantly inhibited CDV-induced cell lesions. Further analysis showed that $0.145 \mu \mathrm{g}$ purified MiIFN- $\alpha 2$ protein and $0.28 \mu \mathrm{g}$ purified MiIFN- $\alpha 12$ could suppress 100 TCID $_{50}$ CDV-mediated cell lesions. These data indicate that MiIFN- $\alpha 2$ exhibits the strongest antiviral activity against VSV and CDV.

\section{Discussion}

The fur animal industry is expanding in the Northeast and Western parts of China. However, the health of fur animals has been compromised by viral infections, such as those with CDV, Parvovirus, and Aleutian mink virus. IFN was first recognized on the basis of its anti-viral activity and only later shown to act primarily as an immunomodulator. IFN- $\alpha$ has been identified from different species, but the biological activity of MiIFN- $\alpha$ has not been tested until now. To determine whether MiIFN $\alpha$ also exhibits antiviral activity similar to IFNs from other species, we examined the ability of recombinant MiIFN- $\alpha$ s to inhibit the replication of VSV.

Using RT-PCR, we successfully amplified the predicted 564 bp mink IFN- $\alpha$ cDNA. The homologies of 13 MiIFN- $\alpha$ subtypes were $93.6-99.3 \%$ and $88.8-98.3 \%$ at the nucleotide and amino acid sequence levels, respectively. It is surprising that all the subtypes have the same size, whereas size differences have been reported in other species. In 14 pig IFN- $\alpha$ s, multiple sequence alignment revealed a $C$-terminal deletion of 8 residues in six IFN- $\alpha$ subtypes (IFN- $\alpha 1, \alpha 2, \alpha 3, \alpha 7, \alpha 10$ and $\alpha 11$ ) [17]. 


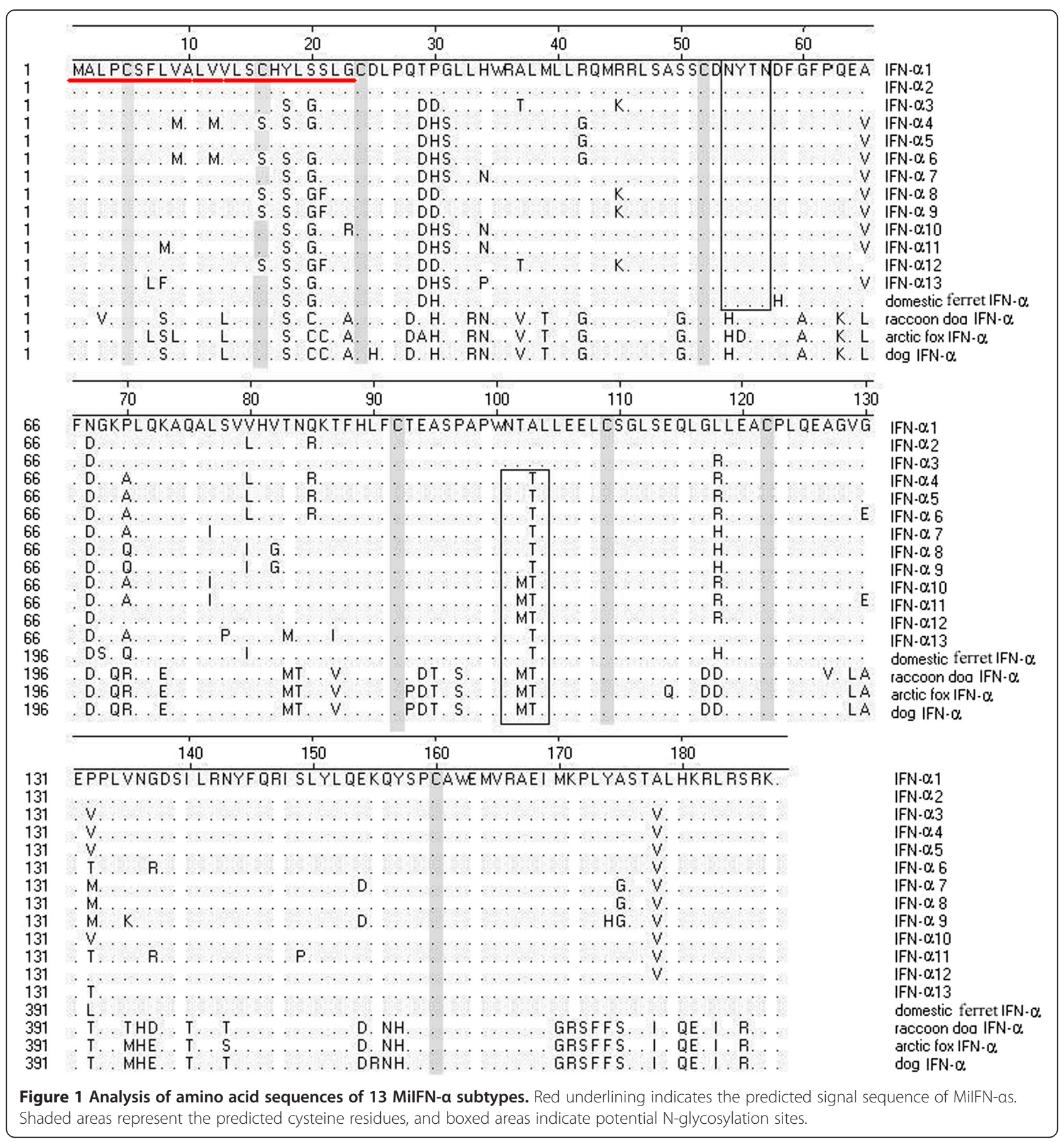

The antiviral activities of intact porcine IFN- $\alpha$ genes are approximately 2-50 times higher than those of the subtypes with C-terminal deletions in WISH cells and 15-55 times higher in PK15 cells. In addition, the size of feline IFN- $\alpha$ subtypes are different; feline IFN- $\alpha 5$ has five additional amino acids inserted at position 139, which are not present in the other four subtypes [18]. More than 10 different subtypes of IFN- $\alpha$ have been reported in mice and 16 or more subtypes have been reported to exist in humans. In mouse, the size of IFN- $\alpha$ subtypes is variable. However, the size of the human IFN subtypes is consistent. In mice injected with plasmids encoding murine $(\mathrm{Mu}) \mathrm{IFN}-\alpha 1, \mathrm{muIFN}-\alpha 4$ or muIFN- $\alpha 9$, and subsequently challenged with murine cytomegalovirus (MCMV), muIFN- $\alpha 1$ exerted the greatest antiviral effect. In another study, eight different human cellderived IFN- $\alpha$ subtypes were tested for their antiviral activities. Human ( $\mathrm{Hu}$ )IFN- $\alpha 8$ was found to be the most 


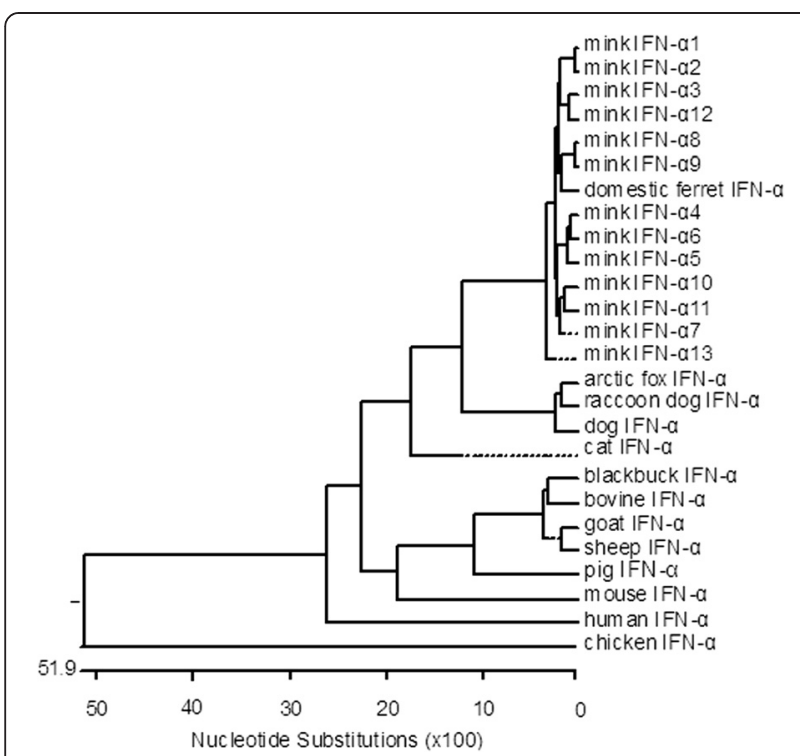

Figure 2 Phylogenetic tree of IFN-a nucleotide sequences of several animal species.

potent, whereas HuIFN- $\alpha 1$ exhibited the least antiviral activity. In the current study, we compared the antiviral effects of the MiIFN- $\alpha$ subtypes. There is no evidence to prove that the strength of antiviral activity is related to the size of the IFN- $\alpha$ subtype. Phylogenetic analysis (Figure 2) further indicated that IFN- $\alpha$ was subdivided into two monophyletic lineages: chicken (avian) and mammalian. The mammalian branch can be divided into carnivores and herbivores. The similarity of mink, domestic ferret, Eurasian badger, giant panda, dog, fox, and cat IFN- $\alpha$ s is consistent with their grouping within the carnivore monophyletic group (which is distinct from other herbivores IFN- $\alpha$ s). Indeed, both gene conversion and gene duplication have shaped the evolution of the IFN- $\alpha$ gene family in eutherian species [19]. The features of MiIFN- $\alpha$ subtype sequences provide more support for this view.

IFN has a broad-spectrum of antiviral effects and represents an ideal choice for the development of antiviral drugs. IFN was the first cytokine approved by the US Food and Drug Administration for clinical application. Among the members of the IFN family, IFN- $\alpha$ has relatively higher antiviral activity. IFN- $\alpha$ has been identified from different species, including birds, rodents, and primates [20]. IFN- $\alpha$ is a multi-gene family, with each member located on the same chromosome within a certain region [19]. One unique characteristic of the IFN- $\alpha$ gene is that it has only one open reading frame (ORF) without any introns. For example, dog has 8 IFN- $\alpha$ genes, cat has 5 IFN- $\alpha$ genes, giant panda has 12 IFN- $\alpha$ genes, and the marmot has 10 IFN- $\alpha$ genes. For each subtype of IFN- $\alpha$ gene of the same species, the sequence of the PCR product is the same whether using genomic DNA or cDNA as the template. In this study, we cloned 13 MiIFN- $\alpha$ genes, including six functional genes and two pseudogenes. In vitro assays showed that only the product of the functional IFN gene had antiviral activity. The reason for the genetic diversity of IFN- $\alpha$ during evolution is still unclear, but different subtypes have distinct biological activities [18]. Tan et al. cloned 12 IFN- $\alpha$ genes from the giant panda and found that IFN- $\alpha 8$, IFN$\alpha 4$, and IFN- $\alpha 10$ had higher activity whereas IFN- $\alpha 11$ had low biological activity in 293 cells (human renal epithelial cells transfected with adenovirus E1A gene) [17]. Furthermore, IFN- $\alpha 3$, IFN- $\alpha 4$, and IFN- $\alpha 8$ demonstrated higher activity in $\mathrm{B} 6$ cells, whereas IFN- $\alpha 3$, IFN- $\alpha 7$, and IFN- $\alpha 10$ showed higher activity in K562 cells [18]. Taira et al. cloned 5 dog IFN- $\alpha$ genes and found that rCaIFN$\alpha 8$ demonstrated high anti-VSV activity. In addition, the anti- canine adenovirus (CAV)- 1 activity of $\mathrm{rCaIFN}-\alpha 8$ in Madin-Darby canine kidney (MDCK) cells was 33-666 times higher than the anti-VSV activity, but rCaIFN- $\alpha 8$ had no effects on CHV-1 [21]. Taken together, these data suggest that IFN- $\alpha$ has many subtypes, most of which have antiviral activity in different types of cells. Although the IFN- $\alpha$ family has many pseudogenes that can be transcribed into mRNA, these pseudogenes have no anti-viral function. The potential roles of the pseudogenes of IFN- $\alpha$ remain to be determined.

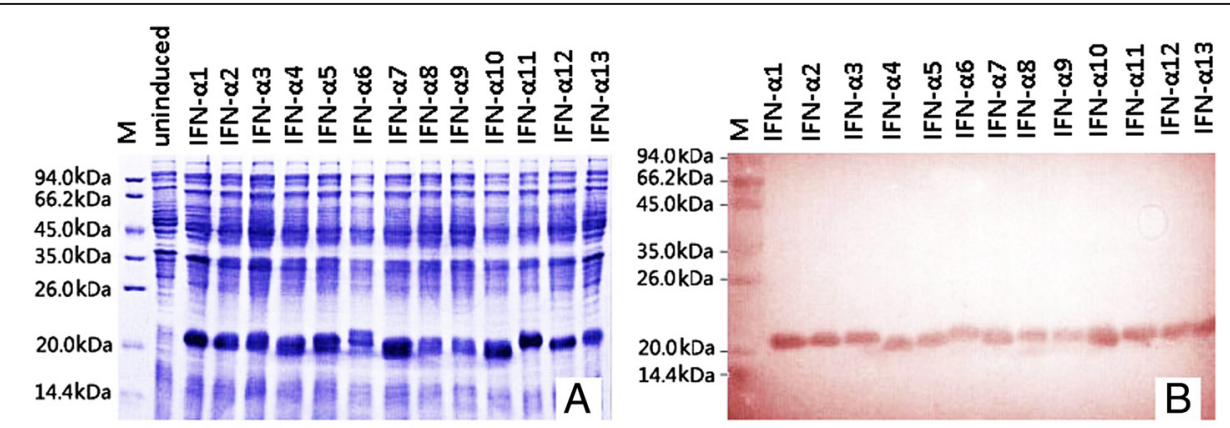

Figure 3 SDS-PAGE analysis of recombinant MilFN-as expressed in E. coli induced by IPTG (A). Western blot analysis of His-tag recombinant MilFN-as by 6-poly histidine monoclonal antibodies (B). 
Effective induction of IFN expression plays an important role during the immune response to viral infection. IFN- $\alpha$ is a multi-gene family consisting of different subtypes with high homology and similar function. However, recent studies have demonstrated that there are functional differences among the subtypes, probably due to the different amino acid sequences. Indeed, our 13 cloned MilFN- $\alpha$ s demonstrated a variety of constituent amino acids in each subtype. MiIFN- $\alpha 4-13$ had two Nglycosylation sites, whereas MiIFN- $\alpha 1-3$ had only one $\mathrm{N}$-glycosylation site. IFN- $\alpha 1-3$, IFN- $\alpha 5$, IFN- $\alpha 7$, IFN$\alpha 10$, IFN- $\alpha 11$, and IFN- $\alpha 13$ had 9 cysteine residues, whereas IFN- $\alpha 4$, IFN- $\alpha 6$, IFN- $\alpha 8$, IFN- $\alpha 9$, and IFN- $\alpha 12$ contained only 8 cysteine residues. Antiviral activity analysis showed that only IFN- $\alpha 1$, IFN- $\alpha 2$, IFN- $\alpha 3$, IFN- $\alpha 8$, IFN- $\alpha 9$, and IFN- $\alpha 12$ had antiviral function. It will be interesting to investigate whether $\mathrm{N}$-glycoslylation sites are essential for the antiviral activity of IFN- $\alpha$.

\section{Conclusions}

In summary, in this study for the first time, we have cloned 13 subtypes of the MilFN- $\alpha$ gene and successfully expressed them in E. coli. Most of the purified recombinant MiIFN- $\alpha$ subtypes demonstrated antiviral activity against VSV and CDV, and MiIFN- $\alpha 2$ exhibited the highest antiviral activity. Therefore, the MiIFN- $\alpha 2$ subtype is a promising candidate for the development of effective antiviral drugs for the fur animal industry.

\section{Methods \\ Reagents}

VSV was provided by Dr. Haidong Zhi from the Institute of Harbin Veterinary Research, Chinese Academy of Agricultural Sciences (CAAS). Canine distemper virus (CDV) strains were from commercial CDV-3 vaccine strains. WISH and Vero cells were purchased from the Chinese Academy of Sciences Shanghai Cell Bank. Plasmid pProEX HTb, E. coli JM109/BL21, and TRIzol were purchased Invitrogen (USA). RPMI 1640 medium was purchased from GIBCO. Lymphocyte isolation reagent was from the Chinese Academy of Medical Sciences. ExTaq polymerase, AMV reverse transcriptase, and Concanavalin A (Con A) were purchased from Sigma (USA). The Ni-NTA protein purification system and anti-6xHis monoclonal antibodies were purchased from Invitrogen.
PCR primers were synthesized by Shanghai Ying-Jun Biotech.

Six-month-old minks were purchased from a fur animal farm in the Jilin Province of China and housed in boxes at the animal house of the Central Laboratory for Animal Diseases of the Institute of Special Animal and Plant Sciences. All animal work and experimental procedures were performed according to the regulations for the administration of affairs concerning experiental animals, which was approved by the state council on October 21, 1988 and promulgated by decree No. 2 of the State Science and Technology Commission on November 14, 1988.

\section{RT-PCR and analysis of IFN- $a$ sequences}

Peripheral blood lymphocytes (PBMCs) were separated under sterile conditions from healthy minks, stimulated with $25 \mu \mathrm{g} / \mathrm{mL}$ ConA for $24 \mathrm{~h}$, centrifuged, and resuspended in $1 \mathrm{~mL}$ TRIzol reagent. Total RNA was isolated by the phenol/chloroform method as described previously [22,23]. cDNA was synthesized from total RNA using Oligod $(\mathrm{T})_{15}$ primer, and PCR was performed with cDNA and primers to amplify IFN- $\alpha$ cDNA [16]. The primer sequences are shown in Table 3. The PCR products were subcloned into the pGEM-T vector for sequencing at Shanghai Ying-Jun BioTech (Invitrogen). The amino acid sequences of the MiIFN- $\alpha$ s ORF were aligned with that of IFN- $\alpha$ s of arctic fox, raccoon, and dog IFN- $\alpha$ from GenBank using DNAStar 5.0 software. A multi-species phylogenetic tree based on the nucleotide sequences of the various IFNs was constructed with DNAStar 5.0 MegAlign software. Signal peptides were predicted using online SignalP 4.1 server (http://www.cbs. dtu.dk/Services/SignalP/). The glycosylation sites were predicted using the online 1.0 NetNGlyc Server.

\section{Construction of mMilFN-a1-13 expression vector}

The PCR products were separated by $1.5 \%$ agarose gel electrophoresis. The gel purified DNA was cut with $B a m \mathrm{H}$ I and Hind III, ligated into the pProEX HTb vector, and transformed into competent $E$. coli /BL 21 cells. Positive clones were validated by PCR and restriction enzymes digestion and sequenced by Shanghai Ying-Jun BioTech. The recombinant plasmid was named pHTb/MiIFN- $\alpha$.

Table 3 Primers used in MilFN- $\alpha$ and mature peptide (mMilFN- $a$ ) gene PCR assays

\begin{tabular}{llll}
\hline Gene fragment & Predicted size (bp) & Primers & Tm$\left.^{\circ}{ }^{\circ} \mathbf{C}\right)$ \\
\hline MilFN-a1-13 & 564 & P1 5'-ATGGCCCTGCCCTGCTCCT- 3' & 50.1 \\
& & P2 5'-TCACTTCCTGCTCCGCAATC-3' & 55 \\
mMilFN-a1-13 & P3 5'-CGGGATCCTGTGACCTGCCTCAG-3' & P4 5'-CCAAGCTTCACTTCCTGCTCCGCAAT-3' \\
\hline
\end{tabular}


Expression and purification of recombinant mMilFN-a1-13 $\mathrm{pHTb} / \mathrm{MiIFN}-\alpha$ s were transformed into E. coli BL21 competent cells and selected with ampicillin. Positive clones were inoculated in $5 \mathrm{ml}$ liquid Luria broth (LB) media and cultured at $37^{\circ} \mathrm{C}$. When the optical density at $600 \mathrm{~nm}$ $\left(\mathrm{OD}_{600}\right)$ reached $0.5,1 \mathrm{mmol} / \mathrm{L}$ IPTG was added to induce protein expression. For purification, the bacteria were centrifuged at 10,000 rpm for $10 \mathrm{~min}$. Following several cycles of freezing and thawing, the bacterial pellet was mixed with $1 \mathrm{mg} / \mathrm{mL}$ lysozme and lysed by sonication on ice. After collection by centrifuging at $4^{\circ} \mathrm{C}$ at $10,000 \mathrm{rpm}$ for $10 \mathrm{~min}$, the pellet was washed with buffer (1\% Triton X$100,50 \mathrm{mmol} / \mathrm{ml}$ Tris $\cdot \mathrm{HCl} \mathrm{pH} 8.0,100 \mathrm{mmol} / \mathrm{mL} \mathrm{NaCl}$ ) and dissolved in $8 \mathrm{~mol} / \mathrm{L}$ urea buffer. Then $50 \% \mathrm{NI}-\mathrm{NTA}$ (4:1) was added and incubated on ice with slow mixing using a magnetic stirrer blender. Finally, the mixture was loaded onto a chromatography column (Novagen) and eluted by serial washing (using $\mathrm{pH}$ 8.0, $\mathrm{pH} 6.3$, and $\mathrm{pH} 4.5$ $50 \mathrm{Mm}$ Tris $\cdot \mathrm{HCl}$ buffer containing $8 \mathrm{M}$ urea). The eluents were separated by $12 \%$ SDS-PAGE and transferred onto a PVDF membrane. The membrane was blocked with $5 \%$ milk in TBST (0.1 phosphate buffer contain $0.5 \%$ Tween20) and incubated with mouse anti-6xHis monoclonal antibody (1:300) at $4{ }^{\circ} \mathrm{C}$ overnight, followed by incubation with goat anti-mouse IgG-HRP (1:2000) at room temperature for $1 \mathrm{~h}$. Finally, the membrane was developed using the TMB Chromogenic Reagent (Sigma, USA).

\section{Antiviral activity assay}

The antiviral activity of $0.5 \mathrm{mg} / \mathrm{mL}$ recombinant IFN- $\alpha$ was determined by cytopathic inhibition assay. WISH cells were plated in 96-well plates and incubated at $37^{\circ} \mathrm{C}$ with $5 \% \mathrm{CO}_{2}$ for $12-18 \mathrm{~h}$. Diluted recombinant IFN- $\alpha$ was added to the cell monolayer and incubated at $37^{\circ} \mathrm{C}$ with $5 \% \mathrm{CO}_{2}$ overnight. Next, the cells were challenged with $100 \mathrm{TCID}_{50} \mathrm{VSV}$, and the plates were incubated at $37^{\circ} \mathrm{C}$ for $1-2$ days. VSV-induced cytopathic effects were assessed by microscopic examination, and IFN- $\alpha$ concentrations were expressed as the inverse dilution that provided protection of $50 \%$ of the cells from VSVinduced cytopathic effects $\left(\mathrm{CPE}_{50}\right)$.

In addition, the antiviral activity of recombinant IFN- $\alpha$ was determined by the inhibition of CDV propagation in Vero cells. The titer of CDV TCID 50 was determined by reference for Reed-Muench method. Vero cells were plated in 24-well plates until the formation of a monolayer. Diluted recombinant IFN- $\alpha$ was added to the cell monolayer and incubated at $37^{\circ} \mathrm{C}$ with $5 \% \mathrm{CO}_{2}$ overnight. Next, the cells were challenged with $100 \mathrm{TCID}_{50} \mathrm{CDV}$, and the plates were incubated at $37^{\circ} \mathrm{C}$ for $1-2$ days. The $\mathrm{CDV}$-induced cytopathic effects were assessed by microscopic examination, and IFN- $\alpha$ concentrations were expressed as the inverse dilution that provided protection of $50 \%$ of the cells from $\mathrm{CDV}$-induced cytopathic effects $\left(\mathrm{CPE}_{50}\right)$.

\section{Competing interest}

The authors declare that they have no competing interest.

\section{Authors' contributions}

$\mathrm{HZ}$ designed the study, performed the experiments, and wrote the manuscript; JZ constructed the plasmids; XC purified the protein; LZ performed sequence analysis; $X B, H B$, and $H L$ evaluated the antiviral activity of recombinant proteins; DZ and MY cultured cells and virus; $X Y$ and WW wrote the manuscript and put forward reasonable proposals. All authors read and approved the final manuscript.

\section{Acknowledgments}

This study was supported by Jilin Science and Technology Development Project (No. 20140520172JH), and Jilin City Outstanding Youth Project (No. 2013625018).

\section{Author details}

'Division of Infectious Diseases of Special Economic Animal, Institute of Special Animal and Plant Sciences, Chinese Academy of Agricultural Sciences, 4899 Juye Street, Changchun 130112, China. ${ }^{2}$ Jilin Teyan Biotechnological Co. Ltd, 388 Liuying West Road, Changchun 130122, China.

Received: 7 March 2014 Accepted: 10 February 2015

Published online: 21 February 2015

\section{References}

1. Chelbi-Alix MK, Wietzerbin J. Interferon, a growing cytokine family: 50 years of interferon research. Biochimie. 2007;89:713-8.

2. Huang L, Cao RB, Wang N, Liu K, Wei JC, Isahg H, et al. The design and recombinant protein expression of a consensus porcine interferon: CoPolFN-a. Cytokine. 2012;57:37-45.

3. Janardhana V, Tachedjian M, Crameri G, Cowled C, Wang LF, Baker ML. Cloning, expression and antiviral activity of IFNy from the Australian fruit bat, Pteropus alecto. Dev Comp Immunol. 2012;36:610-8.

4. Borden EC, Sen GC, Uze G, Silverman RH, Ransohoff RM, Foster GR, et al. Interferons at age 50: past, current and future impact on biomedicine. Nat Rev Drug Discov. 2007;6:975-90.

5. Takaoka A, Yanai H. Interferon signalling network in innate defence. Cell Microbiol. 2006:8:907-22.

6. Kotenko SV, Gallagher G, Baurin W, Lewis-Antes A, Shen M, Shah NK, et al. IFN-lambdas mediate antiviral protection through a distinct class II cytokine receptor complex. Nat Immunol. 2003;4:69-77.

7. Sheppard P, Kindsvogel W, Xu W, Henderson K, Schlutsmeyer S, Whitmore TE, et al. IL-28, IL-29 and their class II cytokine receptor IL-28R. Nat Immunol. 2003;4:63-8

8. Lopušná K, Režuchová I, Betáková T, Skovranová L, Tomašková J, Lukáčiková $L$, et al. Interferons lambda, new cytokines with antiviral activity. Acta Virol. 2013;57:171-9

9. Li HT, Ma B, Mi JW, Jin HY, Xu LN, Wang JW. Molecular cloning and functional analysis of goose interferon gamma. Vet Immunol Immunop. 2007; 117(1-2):67-74.

10. Hoegen B, Saalmüller A, Röttgen M, Rziha HJ, Geldermann H, Reiner G, et al. Interferon-gamma response of PBMC indicates productive pseudorabies virus (PRV) infection in swine. Vet Immunol Immunop. 2004;102(4):389-97.

11. Li L, Sherry B. IFN-alpha expression and antiviral effects are subtype and cell type specific in the cardiac response to viral infection. Viro. 2010;396:59-68.

12. Ma D, Jian D, Qing M, Weidner JM, Qu X, Guo H, et al. Antiviral effect of interferon lambda against West Nile virus. Antivir Res. 2009;83:53-60.

13. Kuruganti $\mathrm{S}$, Accavitti-Loper MA, Walter MR. Production and characterization of thirteen human type-I interferon-a subtypes. Protein expres purif. 2014;103:75-83.

14. Wang J, Cheng S, Yi L, Cheng Y, Yang S, Xu H, et al. Evidence for natural recombination between mink enteritis virus and canine parvovirus. Virol J. 2012;9:252.

15. Song W, Mentink RA, Henquet MG, Cordewener JH, van Dijk AD, Bosch D, et al. N-glycan occupancy of Arabidopsis N-glycoproteins. J Proteomics. 2013;93:343-55.

16. Zhang H, Chai X, Luo G, Wang F, Yi L, Shao X, et al. Cloning, expression and antiviral activity of arctic fox (Alopex lagopus) interferon-gamma gene. J Biot China. 2008;24(9):1625-30. 
17. Tan XM, Tang Y, Yang YF, Song HM, Zhang YZ. Gene cloning, sequencing, expression and biological activity of giant panda (Ailuropoda melanoleuca) interferon-alpha. Mol Immunol. 2007:44:3061-9.

18. Wonderling R, Powell T, Baldwin S, Morales T, Snyder S, Keiser K, et al. Cloning, expression, purification, and biological activity of five feline type I interferons. Vet Immunol Immunop. 2002;89:13-27.

19. Hughes AL. The evolution of the type I interferon gene family in mammals. J Mol Evol. 1995;41:539-48.

20. Hardy MP, Owczarek CM, Jermiin LS, Ejdebäck M, Hertzog PJ. Characterization of the type I interferon locus and identification of novel genes. Genomics. 2004;84:331-45.

21. Taira O, Watanugi I, Hagiwara Y, Takahashi M, Arai S, Sato H, et al. Cloning and expression of canine interferon-alpha genes in Escherichia coli. T J Vet Med Sci. 2005;67:1059-62.

22. Waldvogel AS, Lepage MF, Zakher A, Reichel MP, Eicher R, Heussler VT. Expression of interleukin 4, interleukin 4 splice variants and interferon gamma mRNA in calves experimentally infected with Fasciola hepatica. Vet Immunol Immunop. 2004;97(1-2):53-63.

23. Fung MC, Sia SF, Leung KN, Mak NK. Detection of differential expression of mouse interferon-alpha subtypes by polymerase chain reaction using specific primers. J Immunol Methods. 2004;284(1-2):177-86

\section{Submit your next manuscript to BioMed Central and take full advantage of:}

- Convenient online submission

- Thorough peer review

- No space constraints or color figure charges

- Immediate publication on acceptance

- Inclusion in PubMed, CAS, Scopus and Google Scholar

- Research which is freely available for redistribution 